\title{
Teachers' Elementary School in Online Learning of COVID-19 Pandemic Conditions
}

\author{
Irfan Fauzi ${ }^{*}$, Iman Hermawan Sastra Khusuma ${ }^{2}$ \\ 1 Universitas Pendidikan Indonesia, Indonesia \\ 2 Universitas Negeri Jakarta, Indonesia
}

Corresponding Author: Irfan Fauzi, @if96@upi.edu*

\begin{tabular}{|c|c|}
\hline & ABSTRACT \\
\hline $\begin{array}{l}\text { ARTICLE INFO } \\
\text { Article history: } \\
\text { Received } \\
\text { May 02, } 2020 \\
\text { Revised } \\
\text { May 07, } 2020 \\
\text { Accepted } \\
\text { June 06, } 2020\end{array}$ & $\begin{array}{l}\text { The article aimed to explain in detail the perspectives of elementary } \\
\text { school teachers about online learning in a COVID-19 pandemic condition. } \\
\text { This study used a quantitative approach. The subjects in this study were } \\
45 \text { teachers in Banten and West Java. The results of this study indicated } \\
\text { that teachers understand the context of online learning, but in } \\
\text { implementation there are various problems found, including 1) } \\
\text { availability of facilities, 2) network and internet usage, 3) planning, } \\
\text { implementation, and evaluation of learning, and 4) collaboration with } \\
\text { parents. Online learning help teachers in the COVID-19 pandemic period, } \\
\text { but felt to be ineffective, even } 80 \% \text { of teachers feel dissatisfied thorough } \\
\text { online learning. This research was expected to be an evaluation material } \\
\text { for various parties including education policy makers in conducting } \\
\text { online learning, besides this research can also facilitate other researchers } \\
\text { to develop research on online learning, especially in elementary schools. }\end{array}$ \\
\hline & Keywords: Online Learning, COVID-19 Pandemic, COVID-19 \\
\hline How to cite & $\begin{array}{l}\text { Fauzi, I., \& Khusuma, I. (2020). Teachers' Elementary School in Online } \\
\text { Learning of COVID-19 Pandemic Condition. Jurnal Iqra' : Kajian Ilmu Pendidikan, } \\
\text { 5(1). 58-70. https:// doi.org/10.25217/ji.v5i1.914 }\end{array}$ \\
\hline & http://journal.iaimnumetrolampung.ac.id/index.php/ji/ \\
\hline This is an open access article under the CC BY SA license & $\begin{array}{l}\text { article under the CC BY SA license } \\
\text { https:// creativecommons.org/licenses/by-sa/4.0/ }\end{array}$ \\
\hline
\end{tabular}

\section{INTRODUCTION}

The shifting of live continues change quickly. It can be analysed from the industrial revolution 4.0 which is marked by advances in information technology such as the internet, big data, and artificial intelligence, even new terms emanating from Japan, namely the industrial revolution 5.0 or society era 5.0 that combine a very important element in the 21st century, namely humans and technology or it can be referred to as a concept of a human-centered and technology-based society (Fauzi \& Suryadi, 2020). The development of information technology in the 21st century has caused everyone not to be separated from technology (Martha, Z. D., Adi, E. P., \& Soepriyanto, 2018). In these conditions, education is required to respond positively and more adaptively to changes that occur (Anwar, 2018). As a result it can answer the challenges of the 21st century that are very complex. A study conducted by Janssen \& van der Voort (2016) explained that one of the strategies that must be carried out by every government in dealing with the disruptive era in the 21st century is to provide education and training that provides convenience to 
increase competence, adaptation and provide more ability to do things, and also educate them to become IT experts..

The use of technology in education is often discussed in various events. Selwyn (2016) was disagrees that this is often exaggerated, despite all that the use of information technology has a positive or negative impact on its users (Budiman, 2014; Raja \& Nagasubaramani, 2018 \& Sudarsana, 2018). When looking at a survey conducted by the Indonesian Internet Network Providers Association (APJII) in 2016 APJII (2016) explained that 132.7 million Indonesians were connected to the internet, and at the age of children and adolescents (10-24 years) internet users in Indonesia totaled 24.4 million of the total 132.7 million people, this shows that the use of information technology by children and adolescents in Indonesia are very high. Thus, this potential should be utilized by education by involving information technology in aspects of learning activities. Information technology can be used in improving the quality of learning as well as making information technology as a medium in delivering learning material, as a means of distributing teaching materials by utilizing the internet network, and as a life skills education (Cholik, 2017).

Candra (2016) reported that the use of technology in Indonesia is still rarely carried out in learning activities, fear of the adverse effects caused by technology becomes the main thing teachers reject the use of technology in children. However, everything changed when the COVID-19 pandemic occurred, the corona virus which initially occurred in Wuhan, China in December 2019, has spread to various countries in the world so that this results in abnormal life activities, all activities both work and study carried out at home and this also applies in Indonesia. So the learning system which was originally directly face to face has changed to distance learning that utilizes information technology or it is called online learning.

The term online learning model was originally used to describe learning systems that utilize computer-based internet technology (Kuntarto, 2017 \& Baig, 2011). Initially a lot of research on online learning was used at the level of secondary education and higher education (Arif et al., 2018; Dewi, 2017 \& Iqbal et al., 2019), but recently there has been a lot of research on online learning conducted in elementary schools, for instance using zoom, Google classroom (Beach, 2018., \& Yanti et al., 2020). From various studies that have been conducted on online learning many conclude that it is effective and can be applied in education, it is evident from various studies (Larson \& Vontz, 2018; Shelton et al., (2017) \& Wei \& Chou, (2020), even according to Delen \& Liew (2016) that the development of online learning will greatly assist students in considering ways to use self-regulation strategies that are personal, behavioral and environmental. Online learning is a way to be effective to be applied in education, because most of its implementations are at the level of secondary education and higher education who already understand the use of technology. In addition, the implementation of online learning that is carried out is only a trial in a short period of time. It is clear that online learning will greatly affect its effectiveness. Conditions in emergencies (COVID-19 pandemic) as now result in 
all having to do online learning, including in elementary schools. The current study was very different because the age of elementary school children is at 612 years that not all children can use and access information technology. Then, online learning is not done in a very short time, but this has been done several months ago since the existence of COVID-19 pandemic and will continue to be done until the pandemic period is over. From issues above, it is necessary to investigate in detail how the implementation of online learning in elementary schools during the COVID-19 pandemic. Hence, it can help in providing solutions to online learning that will be carried out in elementary school in the future.

According to Rusman (2013) the key to the success of an education is that one is held by the teacher, because the teacher directly touches students in educating. Then, the teacher must also ensure that the learning process runs well because their responsibility and professionalism as a teacher. However, in such conditions becomes very dilemmatic in conducting teaching and learning activities. As a result, it requires the teacher to implement online learning activities, be the reason it is important for educational researchers to examine in detail about how the implementation of online learning is carried out including by the teacher. This article explained in detail how the teacher's perspective on online learning is carried out in elementary schools in the COVID-19 pandemic. The aspects examined in this study are related to the aspects of knowledge, benefits and effectiveness, constraints, and level of satisfaction in implementing online learning conducted by the teacher. It was expected to be able to give an idea of the objective conditions experienced by elementary school teachers in applying online learning. Hence, it becomes an evaluation material for various parties including education policy makers in conducting online learning especially in elementary schools.

\section{METHODS}

This study used a quantitative approach. Creswell (2010) explained that the quantitative approach is a measurement of data carried out in quantitative and objective statistics through scientific calculations derived from a sample of people or residents who are asked to answer questions about the survey to determine the frequency and percentage of their responses. The method used is the survey method. According to Yuliansyah (2016) the survey is one method used to gather information about a group of people or phenomena that occur in the social environment. Survey research is very suitable to be used by researchers in uncovering perspectives related to online learning conducted by teachers in a COVID-19 pandemic. The subjects in this study were 45 elementary school teachers from various regions in Banten and West Java. The instrument used in this study was a survey. As for the survey in the form of open and closed questionnaires, the questionnaire was made in a google form so that it was easily accessed by the teacher.

Data analysis in this study was conducted as follows, 1) open questionnaire analyzed based on inductive content analysis, according to 
(Mayring, 2014) that this content analysis produce response categories based on the coding process of free answers that have been submitted to respondents, this content analysis includes (a) open coding, at this stage the researcher provides notes of the various responses that arise from the respondent, (b) make categorization, researchers do grouping by making categorization based on the themes that emerge, and (c) make an abstraction, at this stage the researcher makes a general description based on the categories that have been obtained. After the content analysis process is done, the response is calculated using descriptive statistics (percentage), then the results are analyzed in detail, and 2) closed questionnaire is calculated using descriptive statistics (percentage) and the results are analyzed in detail.

\section{RESULT AND DISCUSSION}

The survey was given to elementary school teachers in the Banten and West Java regions, and 45 elementary school teachers were obtained who completed the survey with details of 17 male teachers and 28 female teachers. The length of teaching for each teacher varies, from the earliest one, which is 1 year to the longest, 24 years.

Table 1. Long Teaching Teacher

\begin{tabular}{|c|c|}
\hline Ages (years) & Percentage \\
\hline $1-5$ & $75,6 \%$ \\
$6-10$ & $2,8 \%$ \\
$11-15$ & $8,3 \%$ \\
$16-20$ & $6,9 \%$ \\
$20-25$ & $0,4 \%$ \\
\hline
\end{tabular}

In a simple context, teachers understand the essence of an online learning that is learning done by utilizing internet facilities with the help of various technologies or learning that is done online. However, it is not enough to illustrate how online learning is happening in the field, especially in elementary schools.

The COVID-19 pandemic condition requires all teachers to change learning patterns. There are no choices regarding the learning system used and the only learning system that can be applied is to use online learning. It is the reason that online learning is very helpful in conveying learning to students in an emergency. It is evident from the results of a survey conducted that $82.6 \%$ of teachers admitted that this helped them greatly, as can be seen from the picture below. 
Figure 1. Teachers' Responses to the Impacts or Benefits of Online Learning

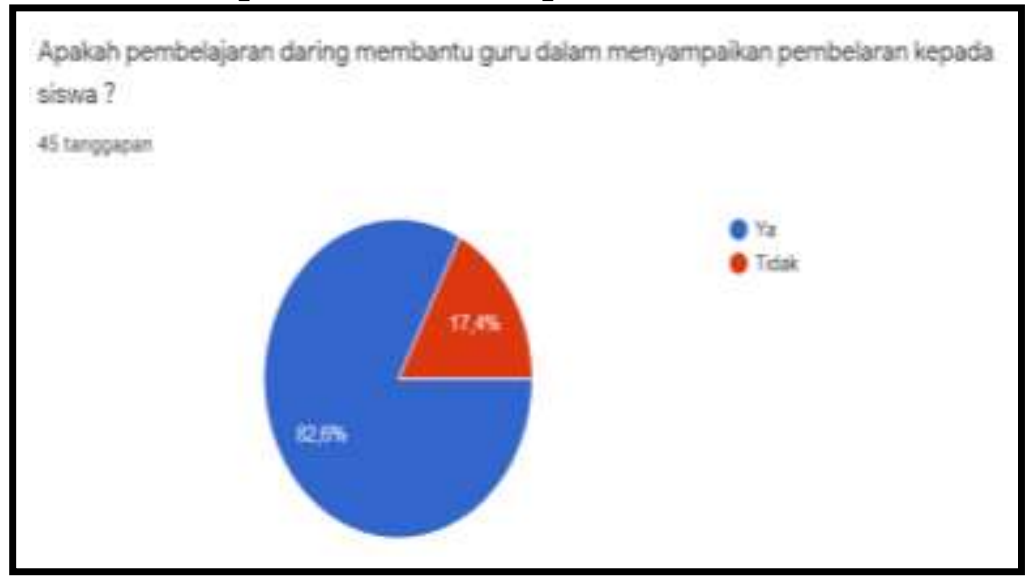

The same statement was said by Sanjaya (2020) that in an emergency situation, online learning will help in implementing learning, because technology can be a bridge for teaching staff in the transfer of knowledge to students. However, It is not directly proportional to the effectiveness of online learning, $73.9 \%$ of teachers consider that online learning is not very effective to be applied in the learning process. The ineffectiveness is caused by several things, including the constraints of the teacher in implementing online learning, while the constraints are presented in the table below.

Table 2. Teachers' Obstacles in Implementing Online Learning

\begin{tabular}{|c|c|}
\hline Obstacles & Percentage \\
\hline Poor facilities availability & $25 \%$ \\
\hline Internet Connection & $22 \%$ \\
\hline Expensive internet quota fees & $12 \%$ \\
\hline Difficulty giving an objective assessment & $8 \%$ \\
\hline $\begin{array}{l}\text { Making teaching materials takes a lot of } \\
\text { time }\end{array}$ & $7 \%$ \\
\hline $\begin{array}{l}\text { Difficulty measuring student } \\
\text { understanding }\end{array}$ & $5 \%$ \\
\hline $\begin{array}{l}\text { Difficulty teaching in low class because } \\
\text { many children still cannot read }\end{array}$ & $5 \%$ \\
\hline Parents who are less cooperative & $5 \%$ \\
\hline $\begin{array}{l}\text { Difficulty explaining the material in } \\
\text { detail }\end{array}$ & $5 \%$ \\
\hline Giving awards is not very memorable & $3 \%$ \\
\hline Difficulties in conditioning students & $3 \%$ \\
\hline Total & $100 \%$ \\
\hline
\end{tabular}

Based on the table above shows that the problems found in online learning that have been done can be grouped into 4 namely 1) availability of facilities, 2) network and internet usage, 3) planning, implementation, and evaluation of 
learning, 4) collaboration with parents. Online learning must be supported by adequate facilities. The fact that $25 \%$ of teachers think that not all students have the communication tools to do online learning. It is the main obstacle found in implementing online learning in elementary schools, besides that adequate internet network access also very influential on the implementation of online learning. Husamah (2013) reported if the network is inadequate, it will affect the learning that is carried out. So that it will be ineffective, $22 \%$ of teachers say that when learning takes place the network is very weak, and influences the ongoing learning process. It can be seen from the pictures in below.

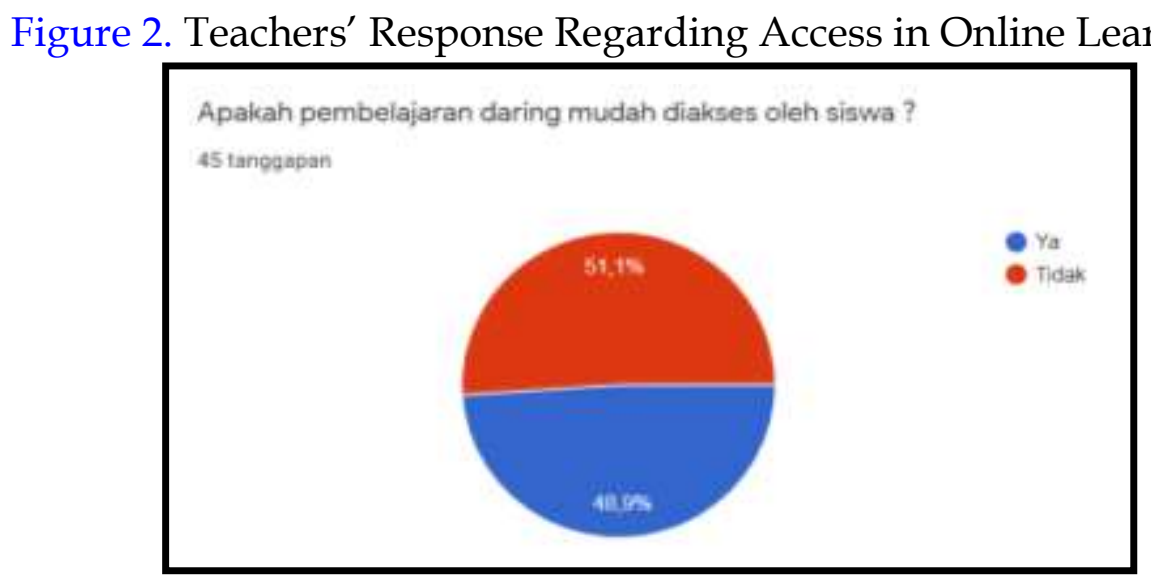

From the picture above $51.1 \%$ of teachers mentioned that online learning is difficult to access by students. It is the reason that network factors are crucial in online learning activities. In addition, teachers who normally plan, implement, and evaluate learning with a system that is directly face to face are forced to apply it in the online system. It is the obstacle for teachers in implementing online learning. Teachers are also very difficult to collaborate with parents, at the beginning of the COVID-19 pandemic period for 1-2 weeks. The role of parents is very visible and involved in implementing online learning, but after that many parents who ask the teacher to only send assignments to be done by children, because often clashes with other parents' tasks/work.

It is also necessary to analyze the content of the teaching materials created and the applications used in carrying out online learning. The content of the teaching materials made by the teacher is explained in the figure below. 
Figure 3. Teachers' Response Related to the Use of Teaching Material Content

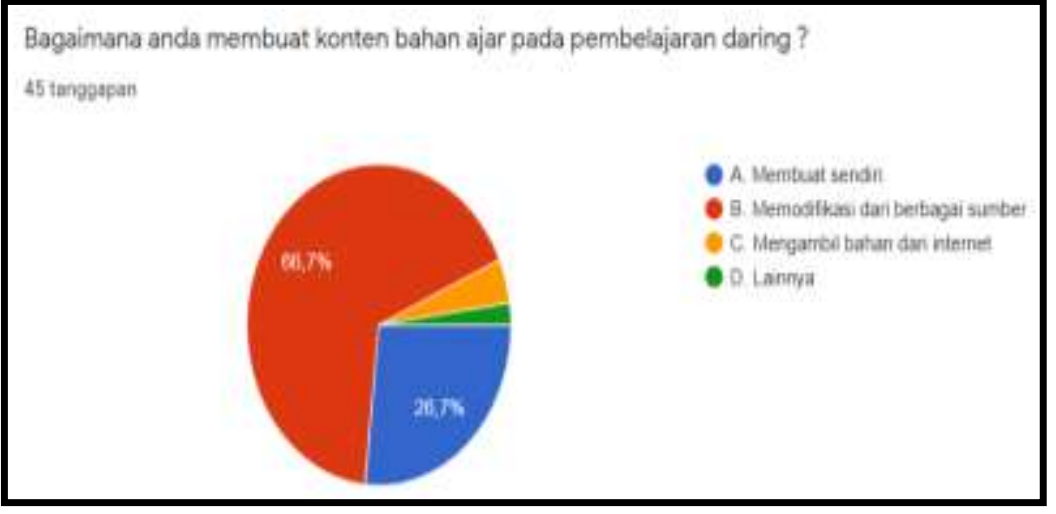

The results showed that $66.7 \%$ of teachers modified teaching materials from various sources to give to students. The remaining $26.7 \%$ of teachers made their own teaching materials, $4.4 \%$ of teachers directly took from the internet and $2.2 \%$ answered from the others. Because the context is online learning. The content of teaching materials created does not use objects in a concrete way, but uses a variety of teaching materials using e-learning platforms. So that they are easily accessed by students to study at home.

Table 3. The form of Teaching Materials Made by the Teacher

\begin{tabular}{|l|c|}
\hline Teaching Materials & Percentage \\
\hline Audio visual & $44,4 \%$ \\
Tex & $22,2 \%$ \\
Visual & $9,7 \%$ \\
Animation & $7 \%$ \\
Audio & $5,5 \%$ \\
Games and & $4,2 \%$ \\
simulations & $7 \%$ \\
Others & $\mathbf{1 0 0 \%}$ \\
\hline \multicolumn{2}{|c|}{ Total } \\
\hline
\end{tabular}

From the table above shows that $44.4 \%$ of teachers often create media in the form of audio visual, it is caused because according to him audio visual is a very interesting form of content to be taught to students in this COVID-19 pandemic. this is also in accordance with the opinion of Foutsitzi (2018) that the use of audio visual media can provide change and experience in the learning process because the images in audio visual media are not static images but animated images so that audio visual media has more graphic advantages and is seen as a media that is attractive. In addition, in implementing online learning, there are several main applications that are often used by teachers. The use of the application can be seen from the table below. 
Table 4. The Applications Used by Teachers in Online Learning

\begin{tabular}{|l|c|}
\hline \multicolumn{1}{|c|}{ Applications } & Percentage \\
\hline Whatsapp & $37 \%$ \\
Zoom & $16 \%$ \\
Google Form & $14 \%$ \\
Google Clasroom & $9 \%$ \\
Edmodo & $7 \%$ \\
Youtube & $5 \%$ \\
Rumah Belajar & $4 \%$ \\
Cisco & $3 \%$ \\
Ruang Guru & $1 \%$ \\
Skype & $1 \%$ \\
Lainnya & $3 \%$ \\
\hline Total & $\mathbf{1 0 0} \%$ \\
\hline
\end{tabular}

Data above shows that the application used by the teacher is very diverse, is in order to build interactive learning so that the learning process can be meaningful. But the use of Whatsapp media is seen as inappropriate media, because whatsapp is made only as a communication medium and is not set to distance learning class or online learning, thus, in whatsapp application there are many shortcomings to be able to apply online learning, and makes learning less meaningful.

Overall online learning continues to be carried out during the COVID-19 pandemic period, not much can be done to create a meaningful learning system amidst conditions like this, and a system that can only be used so that students continue to learn is to use online learning, while the satisfaction response the teacher is presented in the image below.

Figure 4. Response of Teacher Satisfaction to Online Learning

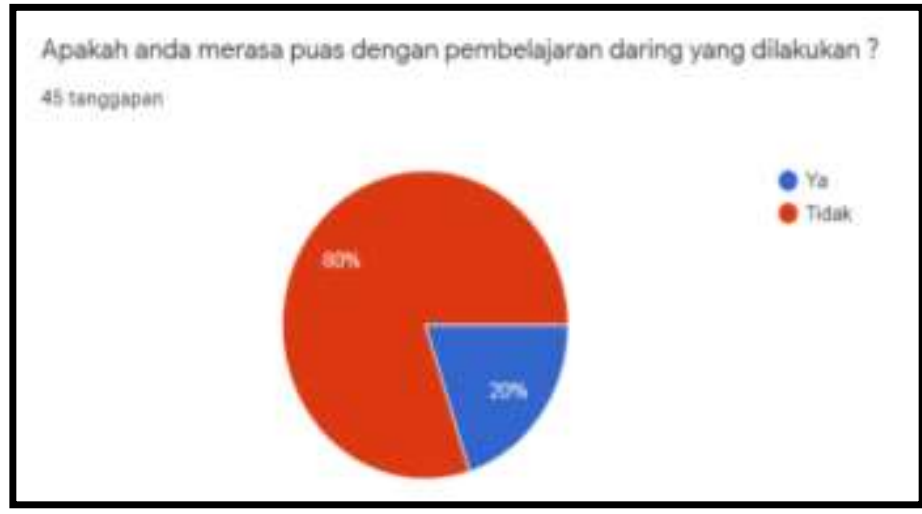


Data above shows that $80 \%$ of teachers feel dissatisfied with online learning, and $20 \%$ of teachers feel satisfied. This dissatisfaction is not without reason, because of the many problems or limitations found in conducting online learning.

The results of this study indicate that the COVID-19 pandemic has had a major impact and change in the educational process. According to Purwanto et al., (2020) that the impact was also greatly felt by students, parents and teachers. In this case, unpreparedness to do online learning is the reason for learning to be ineffective, it is based because online learning is seen as something that is difficult to implement, need some components to be able to do it like facilities, internet access, readiness to learn (teacher, students and material) and parent collaboration, it is also explained by Wicaksono \& Rachmadyanti (2016) that the ineffectiveness of online learning can occur because 1) the media needed is very large and varied, 2) the unequal facilities owned by students, and 3) Lack of teacher, student and parent knowledge on the use of technology.

Figure 5. Online Learning Perception

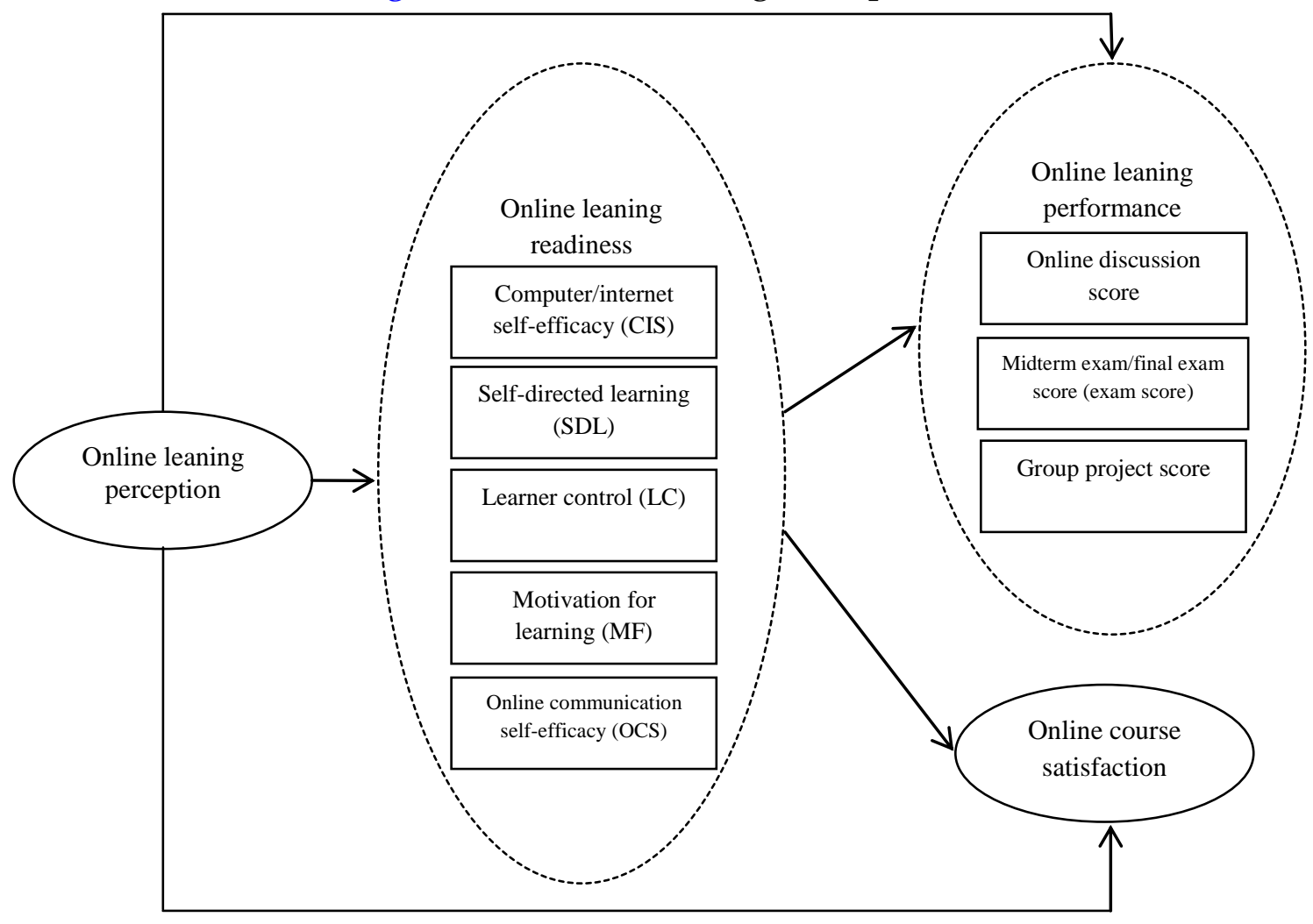

The picture above shows that online learning readiness would greatly affect student performance and satisfaction. So it can be said that the teacher's role in building online learning readiness is the key to learning success. This research is an evaluation material for various parties in implementing online learning, especially in elementary schools. While the obstacles found that must be anticipated. In addition, this research can be used as material in developing 
online learning. Thus, it can be applied in education, especially in elementary schools.

The results of this study clearly show different from previous studies, if in previous studies explained how online learning is very effective to be implemented, but under different conditions, the implementation of online learning that has been done in elementary schools during emergencies (COVID19 pandemic) become ineffective because of various obstacles experienced when doing online learning. These obstacles must be anticipated and find solutions. So that online learning in elementary schools during emergencies becomes effective and can still be applied. The readiness of teachers, students and parents is the key to the success of online learning during this emergency; teachers and parents must be able to work well together. Because the majority of students, especially in elementary schools, can not be used and accessed technology. So, the role of parents is needed to be able to guide their children in using technology, during online learning. In addition, the use of interactive teaching materials and learning applications is very important for the learning process. In the learning activities, there are some things that must be considered by the teacher, including learning readiness, learning performance, and learning satisfaction (Hung et al., 2010). In detail, these three things are explained in the figure below.

\section{CONCLUSIONS}

Online learning was as a system that can help teachers to carry out the learning process in he COVID-19 pandemic, but this is not directly proportional to its effectiveness. $73.9 \%$ of teachers consider that online learning is not effective. Because many problems are found, for instance 1) availability of facilities, 2) network and internet usage, 3) planning, implementation, and evaluation of learning, and 4) collaboration with parents. In addition in making teaching materials, most teachers modify material from various sources and the content that is often created is audio visual. As many as $37 \%$ of teachers use the whatsapp application as a medium for online learning. During these online learning activities $80 \%$ of the teachers were dissatisfied. This research is expected to make a real contribution in Indonesian education, especially in evaluating online learning that has been done. In addition, this research is expected to facilitate various parties to study and develop online learning so that it can be applied in emergencies as it is today.

\section{ACKNOWLEDGEMENTS}

The author would like thank to the various parties who have helped in completing this research, especially to teachers in Banten and West Java who have taken the time to fill out the questionnaire that researchers made.

\section{AUTHOR CONTRIBUTION STATEMENTS}

This research is a collaborative study based on anxiety towards online learning during the COVID-19 pandemic. IF and IHSK jointly design research, 
collect data, and conduct analysis of the data obtained. Furthermore, this research can be completed properly.

\section{REFERENCES}

Anwar, M. (2018). Inovasi Sistem Pendidikan. Inspiratif Pendidikan, 7(2), 161-170. https:// doi.org/10.24252/ip.v7i2.7851

APJII. (2016). Penetrasi \& Perilaku Pengguna Internet di Indonesia. Asosiasi Penyelenggara Jasa Internet Indonesia. Google Scholar

Arif, Istyadji, M., \& Syahmani. (2018). Implementasi Problem Based Learning Berbantuan Diskusi Daring terhadap Kemampuan Pemecahan Larutan Penyangga. JCAE, Journal of Chemistry And Education, 1(3), 237244.Google Scholar

Baig, M. A. (2011). A Critical Study of Effectiveness of Online Learning on Students Achievement. I-Manager's Journal of Educational Technology, 7(4), 28-34. https:// doi.org/10.26634/jet.7.4.1391

Beach, P. (2018). Examining Elementary Teachers' Use of Online Learning Environments: An Exploratory Study. Journal of Research on Technology in Education, 50(1), 34-47. https:/ / doi.org/10.1080/15391523.2017.1383216

Budiman, H. (2014). Peran Teknologi Informasi dan Komunikasi dalam Pendidikan. Al-Tadzkiyyah: Jurnal Pendidikan Islam, 8(1), 31-43. https:/ / doi.org/https:/ / doi.org/10.24042/atjpi.v8i1.2095

Candra, N. (2016). Sekolah Nir Kekerasan: Inspirasi Sekolah Menyenangkan dari Empat Benua. Yogyakarta: Ifada Press.Google Scholar

Cholik, C. A. (2017). Pemanfaatan Teknologi Informasi dan Komunikasi untuk Meningkatkan Pendidikan di Indonesia. Syntax Literate: Jurnal Ilmiah Indonesia, 2(6), 21-30.Google Scholar

Creswell, J. W. (2010). Research Design: Pendekatan Kualitatif, Kuantitatif, dan Mixed. Yogyakarta: Pustaka Pelajar.Google Scholar

Delen, E., \& Liew, J. (2016). The Use of Interactive Environments to Promote Self-regulation in Online Learning: A Literature Review. European Journal of Contemporary Education, 15(1), 24-33. https:// doi.org/10.13187/ ejced.2016.15.24

Dewi, L. (2017). Designing Online Learning in Higher Education Institution: Case Study in Curriculum and Instruction Course at Indonesia University of Education. Edutech, 16(2), 205-221. https://doi.org/https:/ / doi.org/10.17509/e.v16i2.7616

Fauzi, I., \& Suryadi, D. (2020). Didactical Design Research untuk Mengembangkan Kompetensi Pedagogik Guru di Sekolah Dasar. Inventa: Jurnal Pendidikan Guru Sekolah Dasar, 4(1), 58-68. https://doi.org/https://doi.org/10.36456/inventa.4.1.a2207

Foutsitzi, A. (2018). Images in Educational Textbooks and Educational Audiovisual Media. European Journal of Language and Literature, 10(2), 30. https://doi.org/10.26417/ejls.v10i2.p30-33

Hung, M. L., Chou, C., Chen, C. H., \& Own, Z. Y. (2010). Learner Readiness for Online Learning: Scale Development and Student Perceptions. Computers 
and Education, 55(3),

https:/ / doi.org/10.1016/j.compedu.2010.05.004

Husamah. (2013). Pembelajaran Bauran (Blended Learning). Jakarta: Hasil Pustaka. Iqbal, M., Latifah, S., \& Irwandani. (2019). Pengembangan Video Blog (Vlog) Channel Youtube dengan Pendekatan STEM sebagai Media Alternatif Pembelajaran Daring. Inovasi Pembangunan - Jurnal Kelitbangan, 7(2), 135148. https:// doi.org/https:// doi.org/10.35450/jip.v7i2.140

Janssen, M., \& van der Voort, H. (2016). Adaptive Governance: Towards a Stable, Accountable and Responsive Government. Government Information Quarterly, 33(1), 1-5. https:// doi.org/10.1016/j.giq.2016.02.003

Kuntarto, E. (2017). Keefektifan Model Pembelajaran Daring dalam Perkuliahan Bahasa Indonesia di Perguruan Tinggi. Journal Indonesian Language Education and Literature, 3(1), 99-110. https://doi.org/http:/ / dx.doi.org/10.24235/ileal.v3i1.1820

Larson, L., \& Vontz, T. (2018). An Alternative Pathway to Elementary Teaching. Educational Considerations, 44(1), 1-6. https://doi.org/10.4148/01469282.2164

Martha, Z. D., Adi, E. P., \& Soepriyanto, Y. (2018). E-book Berbasis Mobile Learning. Jurnal Kajian Teknologi Pendidikan, 1(2), 109-114.Google Scholar

Purwanto, A., Pramono, R., Asbari, M., Santoso, P. B., Wijayanti, L. M., Hyun, C. C., \& Putri, R. S. (2020). Studi Eksploratif Dampak Pandemi COVID-19 Terhadap Proses Pembelajaran Online di Sekolah Dasar. Journal of Education, Psychology, and Counseling, 2(1), 1-12.Google Scholar

Raja, R., \& Nagasubaramani, P. C. (2018). Impact of Modern Technology in Education. Journal of Applied and Advanced Research, 3(Suppl. 1), S33-S35. https://doi.org/https:/ / dx.doi.org/10.21839/jaar.2018.v3S1.165

Rusman. (2013). Model-model Pembelajaran, Mengembangkan Profesionalisme Guru. Jakarta: Rajawali Press.Google Scholar

Sanjaya, R. F. (2020). 21 Refleksi Pembelajaran Daring di Masa Darurat. Semarang: Universitas Katolik Soegijapranata.Google Scholar

Selwyn, N. (2016). Minding Our Language: Why Education and Technology is Full of Bullshit ... and What Might be done about it. Learning, Media and Technology, 41(3), https://doi.org/10.1080/17439884.2015.1012523

437-443.

Shelton, B. E., Hung, J. L., \& Lowenthal, P. R. (2017). Predicting Student Success by Modeling Student Interaction in Asynchronous Online Courses. Distance Education, 38(1), 59-69. https://doi.org/10.1080/01587919.2017.1299562

Sudarsana, I. K. (2018). Optimalisasi Penggunaan Teknologi dalam Implementasi Kurikulum di Sekolah (Persepektif Teori Konstruktivisme). Celta: Junral Ilmu Pendidikan, 1(1), 8-15. http:/ / orcid.org/0000-0001-5800-6841

Mayring, P. (2014). Qualitative content analysis: theoretical foundation, basic procedures and software solution. Google Scholar 
Wei, H. C., \& Chou, C. (2020). Online Learning Performance and Satisfaction: Do Perceptions and Readiness Matter?. Distance Education, 41(1), 48-69. https://doi.org/10.1080/01587919.2020.1724768

Wicaksono, V. D., \& Rachmadyanti, P. (2016). Pembelajaran Blended Learning melalui Google Classroom di Sekolah Dasar. Seminar Nasional Pendidikan PGSD UMS \& HDPGSDI Wilayah Timur, 513-521. http://hdl.handle.net/11617/9144

Yanti, M. T., Kuntarto, E., \& Kurniawan, A. R. (2020). Pemanfaatan Portal Rumah Belajar Kemendikbud sebagai Model Pembelajaran Daring di Sekolah Dasar. ADI WIDYA: Jurnal Pendidikan Dasar, 5(1), 61-68. https://doi.org/http://dx.doi.org/10.25078/aw.v5i1.1306

Yuliansyah. (2016). Meningkatkan Response Rate pada Penelitian Survey suatu Study Literature. Jakarta: Imprint Change Publication.Google Scholar

\section{Copyright Holder :}

(c) Fauzi, I., \& Khusuma, I. (2020).

First Publication Right :

(c) Jurnal Iqra' : Kajian Ilmu Pendidikan

This article is under:

(ㅇ)(1) (2) 